\title{
ULTIMATE STRENGTH OF COMPOSITE BEAM WITH WEB OPENINGS SUBJECTED TO COMBINED NEGATIVE BENDING AND AXIAL COMPRESSION
}

\author{
Ma.Bavan ${ }^{1}$, Shahrizan Bin Baharom², Siti Aminah Osman ${ }^{3}$ \\ ${ }^{1,2,3}$ Department of Civil and Structural Engineering, National University of Malaysia, Bandar BaruBangi, Selangor, \\ Malaysia,mmbavan@yahoo.com
}

\begin{abstract}
Ultimate strength of composite beam subjected to combined interaction of negative bending and axial compression containing openings in the web of steel beam are reported with various opening parameters such as shapes, diameter in circle openings, width in square openings and distances between openings. A nonlinear three dimensional finite element model (FEM) was developed for composite beam subjected to combined negative bending and axial compression. The model was validated with available experimental data and it was predicted that the axial load, moment and failure mode at ultimate limit state were with an acceptable agreement between FEM and experiment. A study on the web opening parameters was then carried out with validated finite element model. Finally, it is shown that the ultimate load carrying capacity is reduced with openings in different quotients in the composite beam subjected to combined interaction of negative bending and axial compression.
\end{abstract}

Keywords: composite beam with web openings, combined interaction of negative bending and axial compression, $3 D$ nonlinear FEM models, ultimate limit state, failure mode

\section{INTRODUCTION}

The axial compression, applicable in the high rise buildings due to the wind load where the composite beams are located in the windward side, induces unfavorable phenomenon of failure in the negative bending regions of composite beam near internal supports. A wide range of previous research studies are concentrated in the composite beam with web openings subjected to either positive or negative bending in past 30 years. The behavior and design of composite beams subjected to negative bending and compression was reported by Vasdravellis et al. [2012]. The composite beam with web openings subjected to combined negative bending and axial compression is not covered in literature. Thus, this paper investigates the local buckling and ultimate strength of composite beam with openings on web of structural steel member subjected to combined negative bending and axial compression.

\section{EXPERIMENTAL PROGRAMS REVIEWS}

A composite beam was included in this study, which was experimentally carried out by Vasdravellis et al. [2012] and the composite beam was labeled as CB3. The composite beam dimension and test arrangements are shown in Figure 1. Both vertical and axial loads were applied simultaneously until the failure occurs, vertical load was applied to the steel beam on the middle segment and the axial load was applied on the edge surface of steel beam. The failure state was determined through the failure in material components, and the axial load and moment were presented at failure state as ultimate limit state in results.

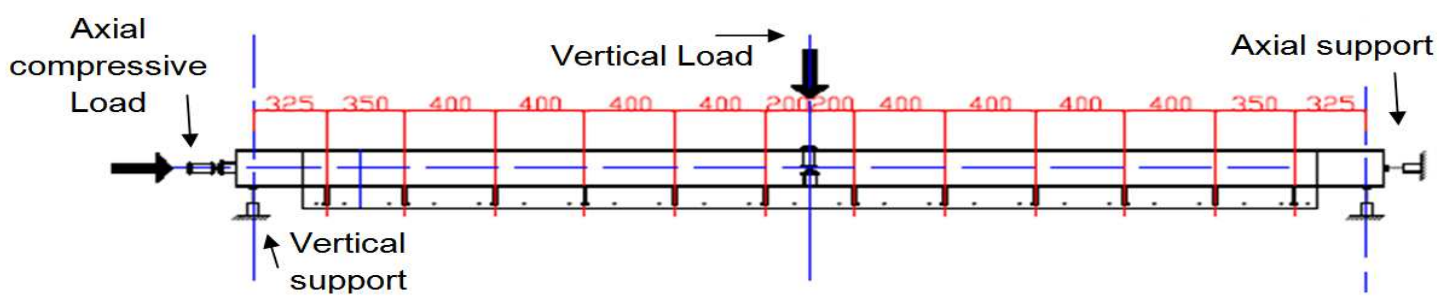

Fig1 Details of test set-up of composite beam subjected to negative bending and axial compression 


\section{FEM MODEL AND VALIDATION}

The FE model was developed in the software named ABAQUS and global finite element analyses were conducted. Three dimensional geometric components were developed to concrete slab, steel beam and shear studs and the element C3D8R was applied to all three dimensional material components except steel beam. The element C3D8I was used to apply to steel beam due to the high concentrated forces applied on steel beam and the type of element T3D2 was applied to reinforcing bars. A uniform slow nodaldisplacement control was maintained in the application of loads and the vertical and axial loads were on the bottom flange of steel beam and on the surface end of steel beam, respectively. The support conditions were made with considering the experimental work and the nodes in the relevant area were protected in the vertical and axial directions. The quasi-static solution in Abaqus explicit dynamic solver was predicted by uniform slow load application and smooth amplitude step. Due to the developed half geometries, the symmetry boundary condition was made along the direction of composite beam. The developed FE model and boundary conditions are shown in Figure 2.

Surface-to-surface contact algorithm was used to determine the contact surfaces. The stiffer body with application of coarser mesh was selected as master surface. The contact property was determined in each surface by tangential and normal behaviours. Penalty friction formulation was selected to its tangential behavior with the coefficient of 0.5 and the hard pressure over closure was selected to its normal behavior with allowing separation behavior. An embedded technique was used to define the bond of wire mesh and concrete slab. All the material components were developed with non-linear behaviors by using the ultimate strength values from the rests carried-out by Vasdravellis et al. [2012]. The concrete material model was developed by plasticity damage models with evaluation of yield surface hardening variables proposed by Lubliner et al [1989] available in Abaqus. The biaxial material property of concrete was used with the parameters for strength hypothesis of concrete recommended by Kmiecik and Kaminski [2011]. The uniaxial stress and strain responses in compression and tension were developed by using the equations proposed by Desay \& Krishnan [1964] and Eurocode [1994], respectively. Structural steel beam characteristics was considered in the behavior of Von Mises yield criterion with isotropic hardening law for preferring large strain analysis proposed by Gattesco [1999]. The material properties of shear stud and reinforcing bars were developed by simplified stress and strain characteristics responses. The convergence study was made with numbers of meshes as course, medium and fine meshes in each material component. In order the developed FE model to be used for parametric studies, the results were compared with experimental work. The FE model was matched in the failure mode at ultimate limit state and the combination of axial compression and moment were with an acceptable agreement. The responses of axial load- vertical load and the comparison of moment-axial load at ultimate limit state between experiment and FE model are shown in Figure 3(a) and 3(b).

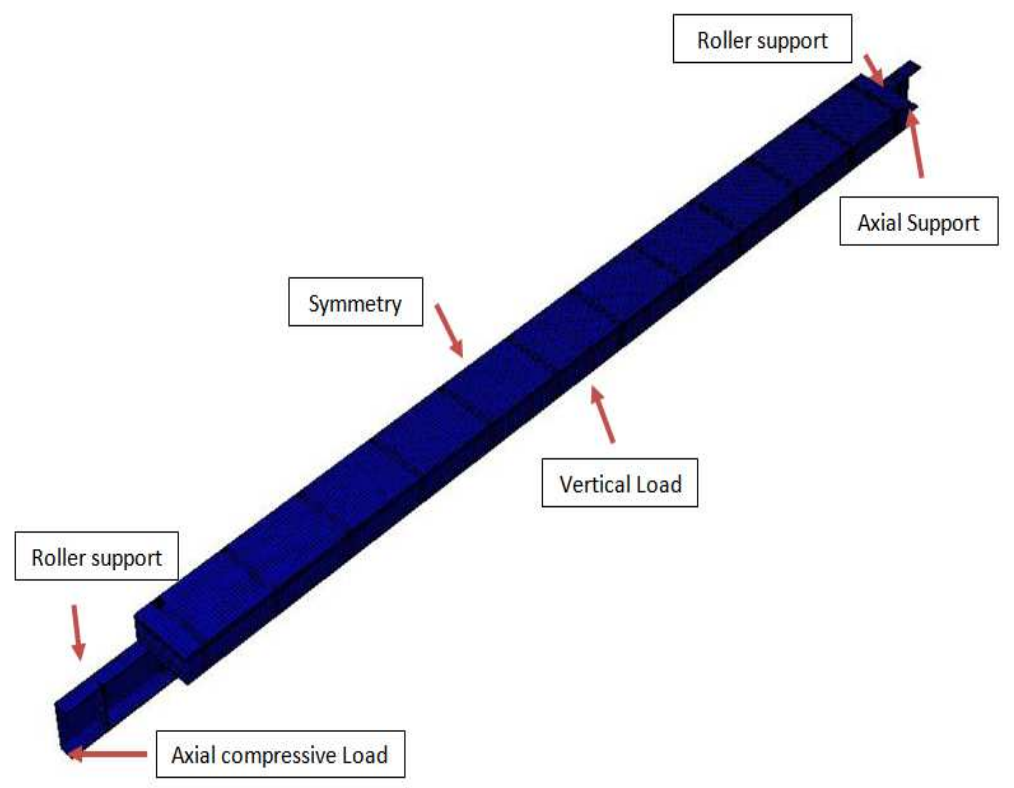

Fig. 2 Finite element model and boundary conditions 

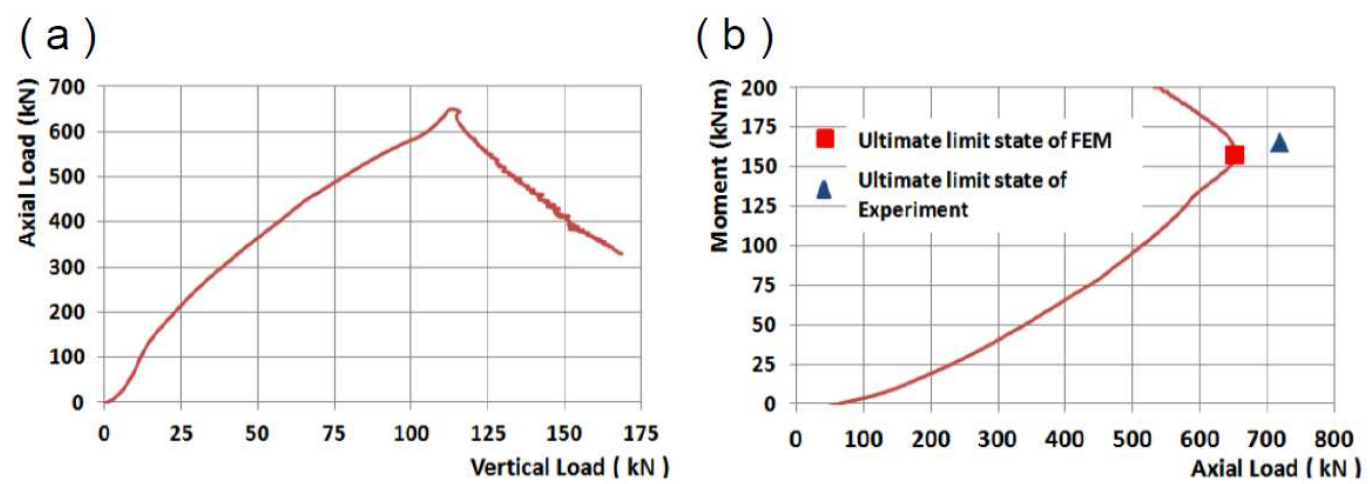

Fig. 3 (a) Responses of axial load- vertical load (b) Comparison of moment-axial load at ultimate limit state

\section{PARAMETRIC FEM STUDY}

The validated FE model was then carried out for a range of parameters. The ultimate strength of composite beam significantly changes due to the influence of axial compression (Vasdravellis et al., 2012). Table I shows the conducted opening parameters in the web of steel beam and a composite beam with openings is shown in the Figure 4. It was observed that the early buckling was occurred in the web and flange of steel beam where the openings were presented in the steel beam. The numbers of openings was influenced on both axial and vertical loads and the strength of composite was reduced highly when high numbers of openings was applied. Meanwhile, the strength of composite beam was slightly reduced or no changes on the applications of low numbers of openings in web. The diameter of circle openings and width of square openings with raises were accelerated the failure state in the compression zone of composite beam and in the narrow areas due to the openings. The possible failure modes such as concrete crushing and cracking failure, buckling in the web and flange of steel beam, shear connection failure and fractures of reinforcing bars were thoroughly alaysed in every model. All parametric FEM of composite beam were failed by local buckling because of the large portion of compressive stresses were in the web of steel beam due to the shifted plastic neutral axial to steel beam from concrete slab.

The moment was calculated in each model by considering axial and vertical load with plastic neutral axis. The moment and axial load are presented in results as ultimate limit state of composite beam where the failure was occurred in the material components. The deviations in axial load, vertical load and moment by means of FEM with openings and without openings are clearly expressed in the Table 1. The FEM labeled as GE1 was weak in vertical load and the failure state was occurred when the axial compressive load was higher than the FEM without openings. It was observed that the middle of steel beam was reached the maximum stresses by local buckling even the stresses developed in the shear studs due to the excess axial compression and the axial load was started to drop down at the point of failure. The responses of axial load and axial displacement of developed FEM are shown in Figure 5(a) to (d). The moment and axial load at ultimate limit state of model are shown with validated model without openings in the Figure 6(a) to (d). The Figure 7(a) and (b) show the typical failure mode of FEM in the development of web buckling where the circle and square openings applied. It could be recommended the placing of longitudinal and transverse stiffeners to be improved the web plate bending and axial compression due to the development of longitudinal and transverse stresses.

\subsection{Final Sections}

The FE models of the composite beam were used to study the ultimate limit state behavior of the composite beam with web openings subjected to combined axial compression and negative bending. The commercial package Abaqus/Explicit solver was used and the applicability of FE models was confirmed with available experimental results in open literature. Early failure state was occurred with the failure modes of local buckling in the web and flanges of steel beam of the composite beam with web openings. It could have been possible to draw a certain conclusions in the behavior of composite beam with web openings subjected to combined interaction of axial compression and negative bending. The axial compression was reduced the strength of composite beam, and the openings in web additionally influence in the combined action of axial compression and vertical load. The investigated parameters such as shapes of openings, distances between openings, diameters of circle openings and widths of square openings gave significant changes in the ultimate limit state of composite beam and major parameters affecting the buckling of steel beam behavior. The axial compressive load has an important role when the composite beam with openings is subjected to combined loadings and thus, the authors strongly feel that the ultimate limit state of composite beam should be implemented with combined actions. 


\section{REFERENCES}

[1] Vasdravellis G, Uy B, Tan EL, Kirkland B, Behavior and design of composite beams subjected to negative bending and compression. J Constr Steel Res 79 (2012) 34-47.

[2] Tsavdaridis KD, Mello CD, Web buckling study of the behaviour and strength of perforated steel beams with different novel web openings shapes. J Constr Steel Res 67 (2011) 1605-1620.

[3] Lawson RM, Lim JBP, Ola SOP, Pull-out forces in shear connectors in composite beams with large web openings. J Constr Steel Res 87 (2013) 48-59.

[4] Lubliner J, Oliver J, Oller S, Onate E. A plastic-damage model for concrete. International Journal of Solids and Structures, Vol.25, 1989, pp. 299-329.
[5] Kmiecik P, Kaminski M., Modelling of reinforced concrete structures and composite structures with concrete strength degradation taken into consideration. Proceedings of conference Archives of Civil and Mechanical Engineering VI, Wroclaw, Poland 2011. P.623-636.

[6] Desayi P, Krishnan S, Equation for the stress-strain curve of concrete. ACIJ Proceed 1964;61(22):345-350.

[7] Gattesco N, Analytical modelling of nonlinear behavior of composite beams with deformable connection. $J$ Constr Steel Res 52 (1999) 195-218.

[8] ABAQUS user's manual, version 6.11, Dassault Systèmes Simulia Corp., Providence, RI, USA.

[9] BS EN 1994-1-1, Euro code 4; Design of composite steel and concrete structure; Part 1.1; general rules and rules for buildings, London (UK); British Standards Institution; 2004.

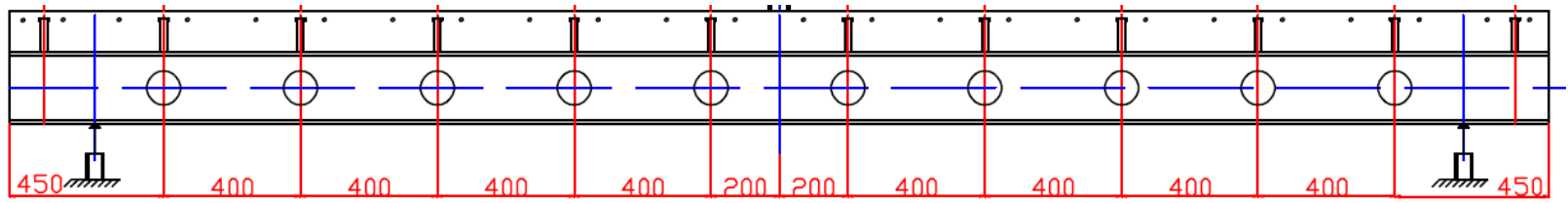

Fig. 4 Composite beam with openings

Table 1 Variation of ultimate limit state in parametric studies

\begin{tabular}{|c|c|c|c|c|c|c|c|c|c|c|c|}
\hline \multirow[b]{2}{*}{ Group } & \multirow[b]{2}{*}{ Type } & \multirow[b]{2}{*}{$\begin{array}{l}\text { Nos. of } \\
\text { opening }\end{array}$} & \multirow{2}{*}{$\begin{array}{l}\text { Distance } \\
\text { between } \\
\text { opening } \\
(\mathrm{mm})\end{array}$} & \multirow{2}{*}{$\begin{array}{l}\text { Diameter } \\
\text { of Circle } \\
\text { opening } \\
(\mathrm{mm})\end{array}$} & \multirow{2}{*}{$\begin{array}{l}\text { Width } \\
\text { of } \\
\text { square } \\
\text { opening } \\
(\mathrm{mm})\end{array}$} & \multicolumn{3}{|c|}{ Ultimate Limit state } & \multirow[b]{2}{*}{$\begin{array}{l}\text { UVFE } \\
\text { /UV }\end{array}$} & \multirow[b]{2}{*}{$\begin{array}{l}\text { UAFE } \\
\text { /UA }\end{array}$} & \multirow[b]{2}{*}{$\begin{array}{l}\text { MFE } \\
/ M\end{array}$} \\
\hline & & & & & & $\begin{array}{l}\text { Vertical } \\
\text { Load } \\
(\mathrm{kN})\end{array}$ & $\begin{array}{l}\text { Axial } \\
\text { Load } \\
(\mathrm{kN})\end{array}$ & $\begin{array}{l}\text { Moment } \\
(\mathrm{kNm})\end{array}$ & & & \\
\hline Experiment & - & - & - & - & - & & 718.00 & 166.00 & & 0.91 & 0.95 \\
\hline $\begin{array}{l}\text { Validated } \\
\text { FEM }\end{array}$ & - & - & - & - & - & 113.41 & 651.54 & 158.01 & 1.00 & 1.00 & 1.00 \\
\hline GA-1 & Circle & 10 & 400 & 150 & - & 97.41 & 592.58 & 133.12 & 1.16 & 1.10 & 1.19 \\
\hline GA-2 & Circle & 10 & 400 & 100 & - & 106.13 & 603.33 & 144.08 & 1.07 & 1.08 & 1.10 \\
\hline GA-3 & Circle & 10 & 400 & 50 & - & 111.44 & 628.20 & 152.24 & 1.02 & 1.04 & 1.04 \\
\hline GC-1 & Circle & 4 & 800 & 150 & - & 110.65 & 598.23 & 145.81 & 1.02 & 1.09 & 1.08 \\
\hline GC-2 & Circle & 4 & 800 & 100 & - & 114.67 & 625.99 & 154.38 & 0.99 & 1.04 & 1.02 \\
\hline GC-3 & Circle & 4 & 800 & 50 & - & 114.72 & 643.45 & 158.64 & 0.99 & 1.01 & 1.00 \\
\hline GE-1 & Square & 10 & 400 & - & 150 & 70.22 & 691.51 & 100.85 & 1.62 & 0.94 & 1.57 \\
\hline GE-2 & Square & 10 & 400 & - & 100 & 102.44 & 613.20 & 140.78 & 1.11 & 1.06 & 1.12 \\
\hline GE-3 & Square & 10 & 400 & - & 50 & 109.87 & 631.72 & 150.92 & 1.03 & 1.03 & 1.05 \\
\hline GG-1 & Square & 4 & 800 & - & 150 & 103.45 & 632.35 & 139.83 & 1.10 & 1.03 & 1.13 \\
\hline GG-2 & Square & 4 & 800 & - & 100 & 113.39 & 630.22 & 153.78 & 1.00 & 1.03 & 1.03 \\
\hline GG-3 & Square & 4 & 800 & - & 50 & 113.95 & 648.57 & 158.54 & 1.00 & 1.00 & 1.00 \\
\hline
\end{tabular}

UVFE, UAFE and MFE denote ultimate vertical load, ultimate axial load and moment of FEM model without opening. UV, UA and M denote ultimate vertical load, ultimate axial load and moment of FEM model in parametric studies. 

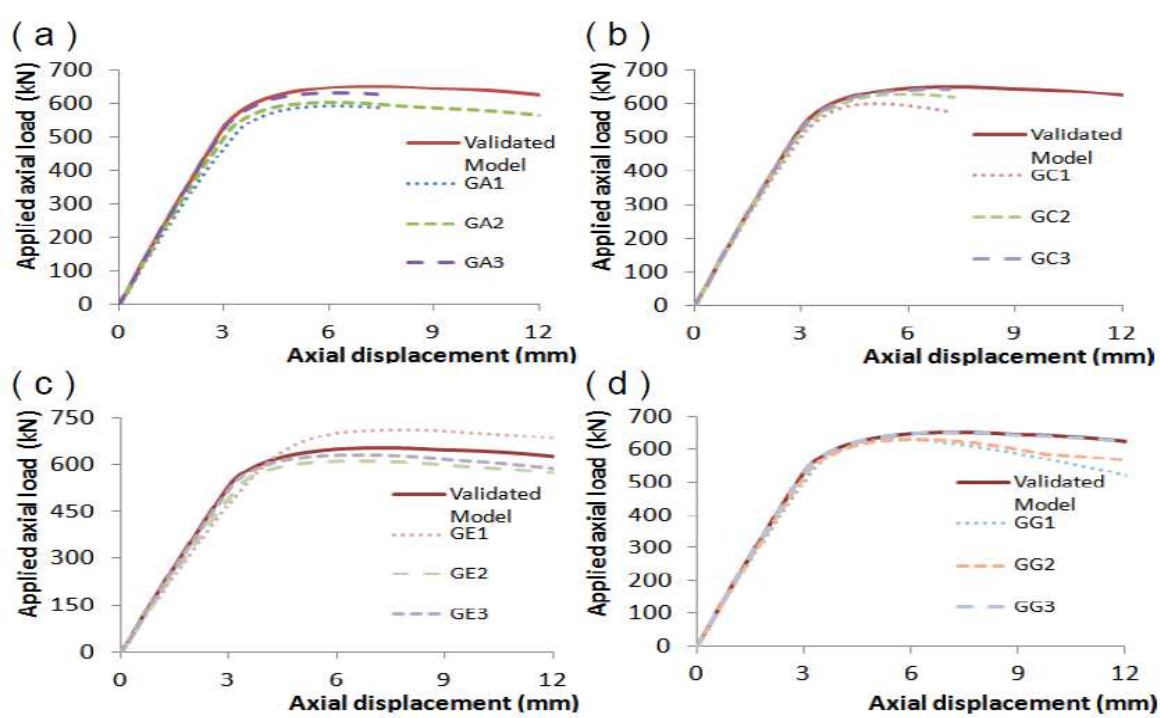

Fig. 5 (a)-(d) Responses of axial load and displacement of parametric FE models
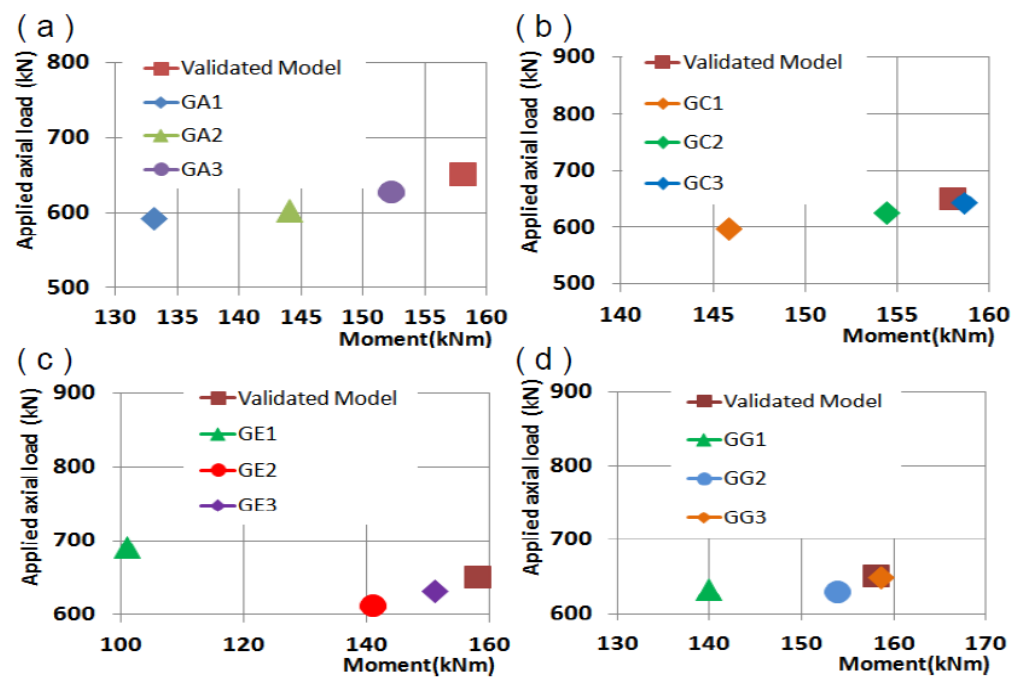

Fig. 6 Responses of axial load and moment of parametric FE models

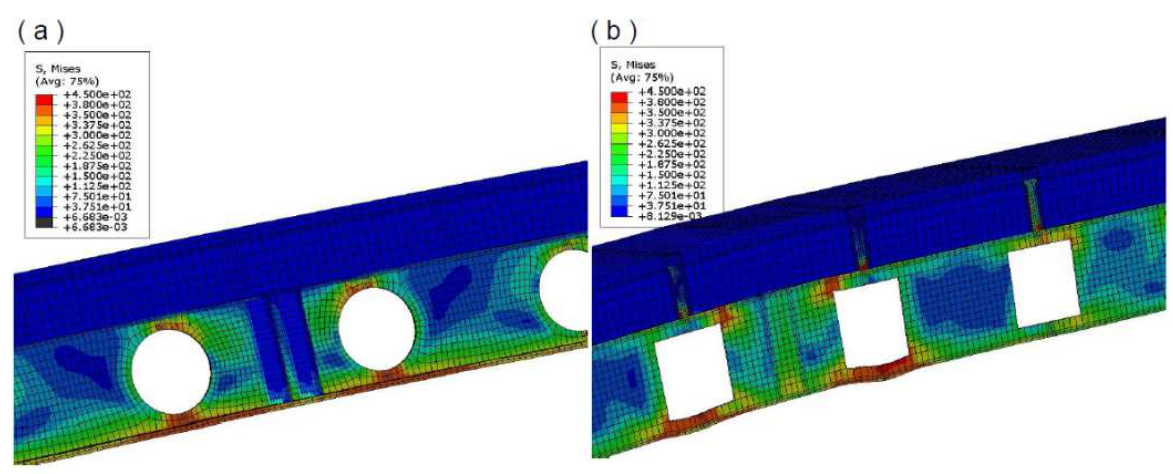

Fig. 7 Stress contour of FE models (a) GA1 (b) GE1 